\title{
The underground economic activity and the desire for corruption in the border region (study of Bengkayang District, West Kalimantan)
}

\author{
Aloysius Hari Kristianto; Jones Parlindungan Nadapdap; \\ Pramatatya Resindra Widya
}

\author{
Department of Management, Institut Shanti Bhuana Bengkayang, Indonesia \\ *To whom correspondence should be addressed.Email: aloysius.hari@shantibhuana.ac.id

\begin{tabular}{|l|l|l|l|l|}
\hline DOI: & Received: & Revised: & Accepted: & Published: \\
10.22437/ppd.v9i4.12871 & 19.05 .2021 & 13.09 .2021 & 19.10 .2021 & 31.10 .2021 \\
\hline
\end{tabular}

\begin{abstract}
Underground economic activity is a situation that needs particular and ongoing attention. This tendency is detrimental to municipal income and is associated with corrupt behaviors and taxation. The purpose of this investigation is to identify and assess the practices of the underground economy, as well as the potential for corrupt conduct and tax evasion. The analytical tool was perhaps a qualitative method with a chosen strategy to identify knowledge sources (respondents) with subjects such as liquor producers, coffee shops, and street food vendors in the Bengkayang border area. The data collection method was carried out using a triangulation approach, namely an in-depth interview, observation, and recording/documentation. The data analysis approach was conducted using data reduction, data presentation, and verification. This study suggests that the presence of corrupt activity in collecting bribes and offering bribes is carried out in cash without going through an automated money processing mechanism such as giving false receipts. Increasing the level of corruption in society will contribute to an increase in the velocity of money. The need for massive surveillance of individuals and the introduction of Penta helix elements to shape synergies between actors and to start integrating and developing electronic/digital structures in any financial activity using the e-government system.
\end{abstract}

Keywords: Corruptive activity, Tax evasion, Underground economy

JEL Classification: E26, E61, H27, J30, O17

\section{INTRODUCTION}

National income is among the indicators used to assess a country's economic growth. It is intended that by correctly calculating national income, it would contribute to society, which is linked to which sectors contribute to society's development and which sectors need to be improved to support the growth of that business. Underground economic activities are prevalent in various countries, both developed and developing. Economic activities are carried out both legally and illegally, and they are not accounted for in the estimate of national income/GDP. (Schneider \& Hametner, 2014). During 2001-2013, Indonesia's underground economic growth was 8.33 percent of GDP. As a result, there is a possible revenue deficit of Rp. 11,172.86 billion, or around 1\% of 
GDP, covers the market output of legitimate and illicit products and services that are exported or purchased illegally (Samuda, 2016).

The findings of Feige's (1990) study of the underground economy are classified into four groups: (1) the illegal economy: the business activity that violates the law, such as the sale of stolen items, enslavement, smuggling, bribery, drug trafficking, and drug trafficking. (2) the unreported economy: failure to submit income to the appropriate tax authority, (3) an unrecorded economy: a lack of statistical information on government income; and (4) an informal economy: commercial players who earn money without a business license, an employment agreement, or a loan from an official financial institution. (Azwar \& Mulyawan, 2017).

Measuring the scale of the underground economy is a difficult task that requires a high level of precision. Optimal fiscal policy in terms of tax collection and administration must be more positive and pro-economic actors for them to become registered business actors and contribute to GDP, which can enhance the income tax subsidies policy of the SME (Small and Medium Enterprises) industry. (Asaminew, 2010). Underground economic activity is defined as an enterprise that generates revenue outside the knowledge of the tax authorities with the intent of evading taxes. It involves the informal sector and the black market, also known as the illegal market. It requires a distinct approach in its execution because the two markets have different implications (Kanao et al., 2010).

A variety of social cognition problems increase the sluggishness of Indonesian SMEs. This social cognition is formed from cultural understanding provided by the Indonesian government and residents via media. Market participants have perceptionrelated flaws, such as systems philosophy, structuralism, and social learning. Due to the inadequacies of Indonesian SMEs, collaborative research based on a philosophical approach to science is required. The low growth rate of SMEs in Indonesia is due to a lack of understanding among business players about how to build a business while considering social aspects such as salaries by government policy, employee health, acceptable business practices, and employees should be adequately rewarded. (Panjaitan et al., 2020).

The parallel market arose due to too strict government regulations and prohibitions on items entering the market. The unregulated sector market is unlawful with the permissible allocation of sales and market share in the revenue. However, the manufacturing and distribution of items on the black market is illegal and violates state law. Small business units, self-employed personnel, unregistered firms, access to minimal credit facilities, and positions in border and peripheral regions are examples of informal sector descriptors (Faal, 2003).

According to Lofchie (1989) in Wardiyanto (2009), tax management policies frequently fail (unsuccessful implementation), problems often emerge due to the poor expertise of professionals, bureaucrats, and civil servants in tax matters and the indiscipline of business players, mistrust of state agencies, the existence of disputes between government workers and the dominant group and the indiscipline of government officials themselves in the execution of the promises they have created (Pravasanti, 2018). In terms of achieving general equilibrium, fiscal policy commitment through moderate tax cuts and constant tight supervision will reduce the amount of underground economic activity and boost the regional economy, thus increasing regional government fiscal revenues (Orsi et al., 2014). The high level of tax pressures 
imposed on business players, the cash supply level, and unemployment add to increased tax avoidance activity (Amoh \& Adafula, 2019).

The findings of the research conducted by Blanchard (2006) explain that the approach of raising tax rates is intended to raise the amount of government revenue, but this move will lead to future tax deviations, so that there is a disincentive to the population in carrying out economic activities; on the other hand, increasing tax rates will enable people to enter the underground economy (Azwar \& Mulyawan, 2017). Increased underground economic growth will cause problems with poor fiscal decentralization policies and low wages due to knowledge of paying low taxes, particularly growing regional economic growth per district (Kanao et al., 2010). The general public's perception of performers in the underground economy is that they are slum, filthy, and disorderly and that the space they occupy is irregular. Well-ordered trade facility also dominates some public spaces, making these business actors feel unorganized, particularly pleasant street vendors. (Schneider, 2014).

On the labor aspect, job restrictions have forced this economic sector to expand and become a possibility for underground economic actors whose sole goal is to live. The underground economy market is distinguished by its relatively small size of operation, reliance on local resources, time and space diversity, and relatively simple accessibility. (Herlina wa ode, 2015). This characterizes the underground economy segment, namely the relatively limited size of operation, local resource reliance, time and location versatility, and relatively simple accessibility (Tanzi \& Fund, 2014).

There is indeed a positive correlation between the extent of corruption and the actions of underground economic players, as demonstrated by the amount of money in circulation in a limited context (currency). From a monetary standpoint, the circulation of currency that cannot be calculated against the measurement of GDP can be counterproductive to state and regional revenues; this should be of concern to both central and state governments (Strapuc \& Hlaciuc, 2019). High levels of corruption diminish public confidence in government authorities, influencing tax evasion and increasing underground economic activity. (Marè et al., 2020). Bribery and suspected acts of corruption are expanding in the underground economy, emphasizing the importance of more efficient and consistent law enforcement (Marliza Mohamed, 2012).

Because of the complicated governmental demands, underground economic actors take different methods in all sectors and seek protection to keep their business running. (Ouédraogo, 2017). To foresee and plan for the issue of underground economic cybercrime, the government must be prepared to take decisive action relating to underground economic operations by partnering with industrial organizations engaging in digital technology. (An \& Kim, 2018). The significance of an integrated framework between scientific disciplines, particularly law and crime, with an integrated approach to the actions of underground economic actors and bribery behavior. (Andreev et al., 2018)

To date, the activities of Indonesia's underground economic actors have not been established and specified; therefore, it is critical to conduct a continuous analysis to devise policies that apply to the circumstances that respond to the conditions of economic actors in each area of Indonesia. Some claim that the underground economy promotes de-industrialization and social isolation, as seen by a reduction in social and individual liberties, which leads to social inequality and poverty. (Chotim et al., 2019). The quantity of underground economic activity will be lowered by making it simpler for micro and small businesses to access the global market. (Hoang, 2020). 
The predicted findings utilizing the consumption-rate growth indicator, larger than economic growth, with an approximate outcome of $40 \%$ of GDP, reveal that corporate activities do not pay taxes, dishonest behaviors, or concealed companies that do not contribute significantly to GDP. (Nizar, 2015). The findings of the research carried out by Faal (2003) from a monetary approach have clarified that the importance of the underground economy in Guyana from 1964 to 2000 with a rate of change in the tax burden could change the market for currency by introducing a major tax component.

Measurement of the scale of the underground economy gives rise to demand variable currency-M1 (monetary money) due to the implementation of Tanzi's standard model of demand for money (Samuda, 2016). In theory, the bank interest rate would negatively influence the demand for money, which implies that if the demand for money falls, the public decides to store money in the form of a deposit. (Kristianto, 2019). Furthermore, when society decides to use the money for commercial operations rather than save in the form of investments on the idea that the return on benefits is larger if the funds are utilized for business, even if the interest rate on the deposit grows, is a different matter (Furuoka \& Munir, 2014).

The findings of this study will examine the government's underhanded activities in the Bengkayang Region. They investigated the underground economy to determine how participants perceive replacing a time-honored method with newer modern technology and the impact on regional growth when contributions are not by such protocols. This study aims to determine the extent of engagement of underground economic players in the local economy. Many examples of corruption at the provincial level in West Kalimantan have been reported in the media. (Korupsi, 2019). The researchers are exploring the demographics of the border area using a phenomenological analysis approach.

\section{METHODS}

This study uses a qualitative phenomenological methodology, which describes stimuli understood holistically by research participants in a spontaneously formed descriptive relational type. This research closely examines their firm's behavior, events, and the person/corporate procedures. Triangulation was employed to collect evidence, including in-depth interviews, participatory observation, and recording in a natural context appropriate for the community and research area.

The study was carried out in the Bengkayang Region of West Kalimantan Province (the research location in the Bengkayang traditional market), where characteristics were not yet optimal. Business actors remained conservative, particularly in understanding business actors' contributions to regional growth, proper retribution/tax payment procedures, and convenience by utilizing a new technological infrastructure to reduce the possibility of extortion on those organizations. Researchers gathered this information from informants who did not want their names published (Table 1).

The process used to choose key informants was purposeful, identifying sites and persons/groups, such as street sellers (both legal and illicit), coffee shops, and booze manufacturers and producers in various areas (Creswell, 2014). The assessment included eight main respondents: two coffee shops, two street vendors, two alcohol makers, and two groceries, all of whom had only a passing knowledge of taxes as a regional contribution. Illegal taxes on business players for regional cleanliness and stability do not provide proof of probable wrongdoing. 
Table 1. Research respondents

\begin{tabular}{ll}
\hline Name & Type of Business \\
\hline A1 & Coffee Shop 1 \\
A2 & Coffee Shop 2 \\
A3 & Street Vendor 1 \\
A4 & Street Vendor 2 \\
A5 & Liquor producer 1 \\
A6 & Liquor producer 2 \\
A7 & Grocery Store 1 \\
A8 & Grocery Store 2 \\
\hline
\end{tabular}

Note: Name does not match identity

The process of data analysis was carried out in three stages: data reduction, data presentation, and data verification to derive conclusions (Miles et al., 2014).

\section{RESULTS AND DISCUSSION}

\section{Respondent characteristics}

The underground economy is a tough phrase to measure. Still, with some information on the features of the economic players, it is possible to describe the real circumstances that exist directly in the Bengkayang region as the research target. Researchers used Cresweel's intentionally select strategy to select respondents, which would be a procedure in which researchers actively and deeply arrange the participants and location (documentation or visual material) of the analysis to better understand the issue under review, with group members ranging in size from three (3) to fifteen (15) persons (Creswell, 2014).

Respondent conditions and characteristics show that business actors have an academic qualification profile of Junior High School (SMP) and Senior High School (SMA), that wages paid by the employer are less than the regional minimum wage in the Bengkayang area, that entrepreneurs do not provide social security benefits to workers, all respondents do not have a Taxpayer Identification Number (NPWP), that workers work more than eight hours per day, and that market players do not engage in entrepreneurial social welfare programs.

\section{Underground economy activities}

An explanation of the facts and economic activities occurring under the surface regarding levies and taxes / illegal business licenses is shown in Table 2.

Table 2. Data on information relating to taxes and licenses

\begin{tabular}{lll}
\hline Name & Retribution & Taxes / License \\
\hline A1 & $\begin{array}{l}\text { There is also no alteration in the payment } \\
\text { of the trashes retaliation; simply pay, and } \\
\text { the storage area is constantly unclean. } \\
\text { NPWP isn't necessary, and retribution is } \\
\text { only a formality. }\end{array}$ & $\begin{array}{l}\text { There is just no socializing on the subject } \\
\text { of NPWP and government business } \\
\text { licenses; there is a need for socialization on } \\
\text { NPWP and Business Licenses and the } \\
\text { benefits of these taxes and NPWP } \\
\text { knowledge. }\end{array}$ \\
\hline $\mathbf{A 2}$ & $\begin{array}{l}\text { Overlying due to payments, select } \\
\text { economic actors are excluded from } \\
\text { paying payments compared to all } \\
\text { business agents. }\end{array}$ & $\begin{array}{l}\text { NPWP is deemed unnecessary or necessary } \\
\text { since there is little profit because, whatever } \\
\text { much the firm appears to be in breach of } \\
\text { the law, the business is not stable (moving) }\end{array}$ \\
\hline
\end{tabular}




\begin{tabular}{lll}
\hline Name & Retribution & Taxes / License \\
\hline A3 & $\begin{array}{l}\text { Officers' support contributions are used } \\
\text { as defensive funds. }\end{array}$ & $\begin{array}{l}\text { NPWP And according to persons engaged, } \\
\text { it is neither required nor beneficial. }\end{array}$ \\
\hline A4 & $\begin{array}{l}\text { Players in the food industry are separated } \\
\text { from coffee shops by a 10\% effectiveness } \\
\text { to sales. }\end{array}$ & $\begin{array}{l}\text { NPWP He considers it unnecessary and } \\
\text { ineffective. }\end{array}$ \\
\hline A5 & $\begin{array}{l}\text { The payments charged are voluntary } \\
\text { donations made without any pressure } \\
\text { from the organization involved, and the } \\
\text { fees paid are for personal use only, not } \\
\text { for official usage. The average security } \\
\text { deposit for a company operator is } \\
\text { between \$200,000 and \$300,000 per } \\
\text { individual. Every month, a commitment } \\
\text { is made, with security teams consisting } \\
\text { of two to three persons. }\end{array}$ & $\begin{array}{l}\text { They argue that NPWP and enterprise } \\
\text { licenses are unnecessary because tiny } \\
\text { businesses that are not considered are side } \\
\text { the board of directors. }\end{array}$ \\
\hline $\mathbf{A 6}$ & $\begin{array}{l}\text { Unscrupulous sources have already } \\
\text { revealed the benefit of giving defense } \\
\text { money in the event of a raid. }\end{array}$ & $\begin{array}{l}\text { Enterprise licenses do not exist since } \\
\text { Long's government appears burdensome } \\
\text { and bureaucratic. }\end{array}$ \\
\hline A7 & $\begin{array}{l}\text { Officials' support contributions are used } \\
\text { as defense funds. }\end{array}$ & $\begin{array}{l}\text { NPWP He considers it pointless and } \\
\text { counterproductive. }\end{array}$ \\
\hline A8 & $\begin{array}{l}\text { While there is a raid, the apparatus will } \\
\text { issue a warning, and the payments will be } \\
\text { made directly to the Agency, not to the } \\
\text { Agency. }\end{array}$ & $\begin{array}{l}\text { NPWP He considers it unnecessary and } \\
\text { ineffective. }\end{array}$ \\
\hline
\end{tabular}

Source: primary data in the form of in-depth interviews at the research location

The term "underground economy" refers to any sort of economic operation that is not recognized and does not contribute to establishing a gross national product. (Badulescu, 2011). There are four types of underground economies: illegal, unreported, unrecorded, and informal. The illegal economy is defined as economic violate human rights or contradicts applicable legal rules; the unreported economy is defined as economic growth that receives money but does not disclose it to tax authorities; and the unrecorded economy is defined as an economic activity that is not reported to tax authorities but should be registered but is not measured in official statistics as well as unofficial economic activity (Feige, 1990).

This study included interviews with underground economy players, which included grocery stores, street sellers, coffee shops, and liquor makers, as represented by two business actors, to determine the underground economy's contribution to the regional economy of the border area. According to the findings of the interviews, the majority of respondents stated that the motivation for starting a company was to make money, which meant that the community maintained a grocery store, market stalls, coffee cafes, and liquor manufacturers to make ends meet.

According to the interviews, most informants stated that the motivation for starting a company was to earn a profit. The community maintained a grocery store, street stalls, coffee cafes, and beer vendors to make ends meet. The report's findings revealed that the working hours enforced were by applicable regulations. That equates to more than eight hours of work every day. This term alludes to a business controlled by the informant that violates applicable regulations, most notably those governing set working hours. This term alludes to a corporation controlled by the informant that violates applicable rules, most notably those governing set working hours. Each source stated that all grocery store owners, street sellers, coffee shops, and alcohol vendors lack 
NPWP or social security in terms of business licenses. The respondents provided many arguments for their business's lack of NPWP and social welfare, as indicated by the subsequent grocery shop traders:

"That there's no politic socializing on the issue of NPWP and enterprise licenses; government socialization on NPWP and business permits, as well as the incentives of these taxes and a knowledge of NPWP, is required." (Grocery Store No. 1)

The third rationale is that you don't need to experience the impact of acquiring an NPWP on your firm; hence you don't require one, as explained in the following line.

"NPWP is thought to be unnecessary or necessary since there is no profit and the firm is now believed to violate the law; the business is not permanent." (Grocery Store No. 2)

"NPWP is nothing more than a catchphrase" (Street Vendor 1).

"NPWP and company licenses are not considered as important by small enterprises or board members, who assume that only large corporations require them" (Coffee shop 1).

Another reason corporate players have stated their opposition to an NPWP is the extensive and long-standing bureaucracy. One of the following business actors stated this.

"All business restrictions are the result of bureaucracy" (Coffee shop 2).

Using an NPWP in the name of a firm by a business performer is one of the markers that the business they manage is authentic. However, there is a requirement that there be no socializing of the necessity of NPWP for companies, such that business players find it difficult to get NPWP and regard NPWP as unnecessary to justify business actors' ongoing engagement in the underground economy.

It's also represented in Rothenberg (2016)'s research on the informal economy sector in Indonesia, which found that economic actors in the informal sector or the underground economy will live in an illegal position because they will not suffer any losses as a result of their enterprises' illegal status. Ultimately, the underground economy practiced by these small businesses will be a drain on both the regional and national economies. (Montenegro, 2010).

According to the research informant, these underground economy dealers pay fees to conduct their enterprises in economic output. The charge in question is for a washing machine and a security deposit. Some sources, however, claim that these funds are discretionary contributions intended for people rather than the right official. It is expressed in the paragraph that follows (Williams, 2015). It is also explained by (Rothenberg et al., 2016) that the engagement of unbridled businesses in the underground economy may have a negative impact on tax revenue, market mechanisms, and productivity. According to the research informant, these shadow economy dealers are likely to conduct their enterprises in economic impact. The price includes a cleaning fee and a safety cost. (Williams \& Horodnic, 2017). This behavior may have a negative impact on the regional economy, income, and the ability for corruption within the apparatuses. The higher the level of corruption in a place, the more underground economic actors in that sector. (Wiseman, 2015). This is demonstrated in the following example:

"The freely donated and for private use gifts include safety in the range of Rp.200 to Rp.300 thousand." The payment is provided monthly, and the security troops who 
arrive are only two or three people." (Coffee shop No. 1)

"When an incident occurs, it is preferable to pay the ransom rather than take preventative steps" (Coffee shop 2).

"If the equipment sends you a warning while in an incident, the money does not go into the agency's wallet." (Liquor producer No. 2)

"Because they involve the local surveillance state, we don't dare to disagree with them, so we pay them, so they don't take over (Liquor Maker 1)

A qualitative research approach is being conducted to better understand the role of the underground economy in the regional economy of the 3T (outermost, in front, and least developed) region. The term "underground economy" refers to all sorts of economic activity that are not registered and do not contribute to forming a gross national/regional product, much less to the regional economy, and are used for personal gain (Strapuc \& Hlaciuc, 2019). Let's look at the market situations of underground economic players amid the economic problems caused by the Covid-19 epidemic. We can see that business actors may still survive, even though many large-scale and respectable business actors have experienced deficits in other circumstances. It is expressed in the statement below.

"As during crisis, price of raw materials rose but purchasing rates remained low." (Vendor on the street No. 1)

"I even serve alcohol and order and import it from neighboring towns, but no one knows about it." (Coffee shop No. 2)

"Wine production fluctuates according to demand, with 2,000 to 3,000 kilos of wine selling for Rp.25,000 every week." (Producer of liquor no. 1)

Depending on this, it is possible to demonstrate that underground business owners can manage a firm even in bad circumstances. Overall, the qualitative study findings indicate that underground economy players can help the economy of the border area by contributing to the government. It matches Rasbin's (2013) research conclusions, which found that the underground economy accounted for 8.33 percent of Indonesia's GDP from 2001 to 2013. The potential for tax losses is likewise quite large, topping $1 \%$ of Indonesia's average quarterly GDP.

\section{Research implication}

To assist in identifying the underground economy. It is critical first to investigate the underground economy, which encompasses the complexities of its relations, identifies the characteristics of the actors involved, and identifies the practices, rules of engagement, values, and culture that govern economic ties between underground economic entities. (Dermawan, 2010). The acceptability of politics allows for tax evasion and unethical behavior enhancement. Political interference and corruption foster a cultural culture in which coercive authorities are rendered useless. (Nurunnabi, 2019). The study of corruption is dominated by public administration and sociology.

On the other hand, economists have done much research on the subject. According to Transparency International, corruption is "the misuse of delegated power for personal benefit." While the cost of corruption has long been examined, there is little evidence that it influences inflation. The connection between corruption and inflation was studied for twenty nations between 1995 and 2015. The estimates show that high levels of corruption enhance inflation rates and that there is a unidirectional causal relationship between corruption and inflation in 10 nations. (Ozsahin \& Ucler, 2017). 
While corruption and incompetent courts will violate ethical principles and have other undesirable repercussions, they should not be allowed to exacerbate social inequality. Furthermore, while the quality of the judiciary has a positive image, it may be the absolute opposite. However, we must emphasize that corruption and method are explained to impact long-term growth, which is why accountability and fighting corruption would result in actual prosperity for the whole community. By essence, whether the comparably wealthy avoid corruption by shifting consumption to other nations or by engaging in unethical tactics to conceal income and consumption from traditional measurements would impact the quality of national balance statistics. Furthermore, distributional changes cannot assess whether corruption and systemic transparency influence social mobility levels. In other words, the demand distribution has altered. Still, it is impossible to predict how probable it is that people and families would fall into a specific distribution segment. When contemplating legislative initiatives to eliminate bribery and improve judicial openness, it is necessary to take caution: unforeseen implications on the distribution margins may need to be addressed deliberately. (Berggren \& Bjørnskov, 2020).

The importance of reducing allegations of bribery, corruption, and criminal abuse with the assistance of honest security services and a member of society. The study's findings indicate that underground economy entrepreneurs do not have an NPWP, which indicates that the firm they run is not licensed with the tax authorities and creates a burden on local government tax collections. Business actors do not have to register a firm because they lack competence legally, do not feel it is required, and the tax authority's complicated legality regulation. As a result, undeveloped regions that should profit from underground commercial activities conducted by corporate players have become a burden. Municipal governments must immediately begin gathering data and establishing initiatives to allow underground economic players to operate the economy and partake in informal economic activity legitimately. It will raise municipal tax income, which will stimulate regional economic growth. Socialization, assistance, and community preparation for key information required for regional progress are critical. (Ozsahin \& Ucler, 2017). The scheme that must be implemented imposes social punishments in the form of yearly reporting on corruption occurrences and repayment for monies that have been utilized twice as much. National policy enforcement is conceivable if regional dynamics and the magnitude of corruption instances are considered. There is a need for stronger penalties for corruption offenders since Indonesian legislation has always conflicted with human rights and extremely dynamic political interests.

\section{CONCLUSION AND RECOMMENDATION}

\section{Conclusion}

According to the findings of this study, the functioning of the underground economy is the total of probable acts of corruption occurring within entities and the amount of income tax raised. Increasing the number of corrupt activities inside the organization may increase the supply of money due to financing the corruption-related deficit. In this regard, a rise in the quantity of income tax collected can likewise increase the revenue collected. Corruption in Indonesia increased last year, as did the amount of income tax collected. As a result, the money supply, the amount of cash possessed by the public, and the demand for deposits in the rupiah currency, have increased. The growth in government capital implies more money accessible to the community to do business. 


\section{Recommendation}

The government is advised to establish a digitally networked framework between government agencies and authorities involved in payment activities, such as taxes, fees, commercial transactions, and the implementation of e-government. So that the public has more access to governance under the supervision of a specific government performance management organization focused on transparency, accountability, speed, responsiveness, and openness.

In addition, the need for the introduction of Penta helix elements to shape synergies between actors and to start integrating and developing electronic/digital structures in any financial activity using the e-government system

\section{REFERENCES}

Amoh, J. K., \& Adafula, B. (2019). An estimation of the underground economy and tax evasion: Empirical analysis from an emerging economy. Journal of Money Laundering Control, 22(4), 626-645. https://doi.org/10.1108/JMLC-01-2019-0002

An, J., \& Kim, H. W. (2018). A Data Analytics Approach to the Cybercrime Underground Economy. IEEE Access, 6(c), 26636-26652. https://doi.org/10.1109/ACCESS.2018.2831667

Andreev, A. S., Andreeva, O. V., Bondareva, G. V., \& Osyak, V. V. (2018). Understanding the underground economy. European Research Studies Journal, 21(2), 814-822.

Asaminew, E. (2010). The Underground Economy and Tax Evasion in Ethiopia: Implications for Tax Policy. Macroeconomic Division Ethiopian Economic Policy Research Institute, 1-26. http://www.csae.ox.ac.uk/conferences/2011edia/papers/130-asaminew.pdf

Azwar, \& Mulyawan, andi wawan. (2017). Analisis Underground Economy Indonesia dan Potensi Penerimaan Pajak. Jurnal Info Artha, 1(1), 60-78. https://doi.org/https://dx.doi.org/10.2139/ssrn.3004254

Badulescu, A. (2011). The underground economy: What is the influence of the discount factor? African Journal of Business Management, 5(16), 7050-7054. https://doi.org/10.5897/AJBM11.1192

Berggren, N., \& Bjørnskov, C. (2020). Corruption, judicial accountability and inequality: Unfair procedures may benefit the worst-off. Journal of Economic Behavior and Organization, 170, 341-354. https://doi.org/10.1016/j.jebo.2019.12.010

Chotim, E. E., Fawzia, D., Halim, P., \& Badruddin, S. (2019). The underground economy, deindustrialization, and poverty: A study on the trade network of textiles and product textiles in Indonesia. International Journal of Innovation, Creativity and Change, 9(1), 95-115. https://www.ijicc.net/images/vol9iss1/9106_Chotim_2019_E_R.pdf

Creswell. (2014). Research Design: qualitative, quantitative and mixed methods approaches. SAGE Publications Inc.

Dermawan, M. K. (2010). Underground Economy Dan Kejahatan Birokrat. Jurnal Masyarakat Dan Budaya, 12(2), 277-306. https://doi.org/https://doi.org/10.14203/jmb.v12i2.113

Faal, E. (2003). Currency Demand, the Underground Economy, and Tax Evasion: The Case of Guyana. IMF Working Papers, 03(7), 1. https://doi.org/10.5089/9781451842432.001

Feige, E. L. (1990). Defining and estimating underground and informal economies: The new institutional economics approach. World Development, 18(7), 989-1002. 
https://doi.org/10.1016/0305-750X(90)90081-8

Furuoka, F., \& Munir, Q. (2014). Unemployment and Inflation in Malaysia: Evidence from Error Correction Model. Philippine Journal of Development, 1(1), 35-45. https://www.ums.edu.my/mjbe/images/mjbe/vol1/article_3.pdf

Herlina wa ode, et. al. (2015). Strategi Pengembangan Usaha Sektor Informal dalam Meningkatkan Pendapatan Pedagang Kaki Lima di Kecamatan Kambu Kota Kendari. Jurnal Administrasi Bisnis (JAB), 3(1), 125-134. https://doi.org/http://dx.doi.org/10.52423/bujab.v3i1.9611

Hoang, H. (2020). The underground economy in transition countries from the perspective of globalization: The case of Vietnam. Revista Amazonia Investiga, 9(29), 234-242. https://doi.org/10.34069/ai/2020.29.05.26

Kanao, Koji, H. dan, \& Shigeyuki. (2010). The size of the underground economy in Japan. Munich Personal RePEc Archive, 24064. https://mpra.ub.unimuenchen.de/21562/

Kristianto, A. H. (2019). Analyzing The Influence Of Interest Rates on Money Demand According to Keynesian Theory. Msdj Shanti Bhuana, 1(1), 38-47. https://journal.shantibhuana.ac.id/index.php/msd/article/view/99

Kristianto, A. H., Widya, P. R., \& Nadapdap, J. P. (2021). The portrait of the underground economy and tax evasion: Descriptive analysis from border region. Journal of Socioeconomics and Development, 4(2), 156. https://doi.org/10.31328/jsed.v4i2.2211

Marè, M., Motroni, A., \& Porcelli, F. (2020). How family ties affect trust, tax morale and underground economy. Journal of Economic Behavior and Organization, 174, 235-252. https://doi.org/10.1016/j.jebo.2020.02.010

Marliza Mohamed. (2012). Estimating the Underground Economy from the Tax Gap: The Case of Malaysia. Malaysian Journal of Economic Studies, 49(2), 91-109. http://ijie.um.edu.my/index.php/MJES/article/download/2859/1033

Miles, Huberman, \& Saldana. (2014). Qualitative Data Analysis (Third Edit). SAGE Publications Inc.

Montenegro, F. S. A. B. C. E. (2010). Shadow Economies All over the World New Estimates for 162 Countries from 1999 to 2007. Policy Research Working Paper WPS5356 5356, 72(3), 779-786. https://doi.org/10.1007/s12665-013-3001-z

Nizar, M. A. (2015). Potensi penerimaan pajak dari underground economy di indonesia. Kajian Ekonomi Dan Keuangan, 15, 1-38. https://doi.org/1410-3249

Nurunnabi, M. (2019). Political Influence and Tax Evasion in Bangladesh: What Went Wrong? Emerald Publishing Limited, 26, 113-134. https://doi.org/10.1108/s1058749720190000026007

Orsi, R., Raggi, D., \& Turino, F. (2014). Size, trend, and policy implications of the underground economy. Review of Economic Dynamics, 17(3), 417-436. https://doi.org/10.1016/j.red.2013.11.001

Ouédraogo, I. M. (2017). Governance, Corruption, and the Informal Economy. Modern Economy, 08(02), 256-271. https://doi.org/10.4236/me.2017.82018

Ozsahin, S., \& Ucler, G. (2017). The consequences of corruption on inflation in developing countries: Evidence from panel cointegration and causality tests. Economies, 5(49). https://doi.org/10.3390/economies5040049

Panjaitan, J. M. P., Timur, R. P., \& Sumiyana, S. (2020). How does the Government of Indonesia empower SMEs? An analysis of the social cognition found in newspapers. Journal of Entrepreneurship in Emerging Economies, 6(1), 1-11. https://doi.org/10.1108/JEEE-04-2020-0087

Pravasanti, Y. A. (2018). Dampak Kebijakan dan Keberhasilan Tax Amnesty bagi 
Perekonomian Indonesia. Kompartemen: Jurnal Ilmiah Akuntansi, 16(1), 84-94. https://doi.org/10.30595/kompartemen.v16i1.2415

Rothenberg, A. D., Gaduh, A., Burger, N. E., Chazali, C., Tjandraningsih, I., Radikun, R., Sutera, C., \& Weilant, S. (2016). Rethinking Indonesia's Informal Sector. World Development, 80, 96-113. https://doi.org/10.1016/j.worlddev.2015.11.005

Samuda, S. J. A. (2016). Underground Economy in Indonesia. Buletin Ekonomi Moneter Dan Perbankan, 19(1), 39-56. https://doi.org/10.21098/bemp.v19i1.599

Schneider, F. (2014). In the shadow of the state - the informal economy and informal economy labor force. Danube, 5(4), 227-248. https://doi.org/10.2478/danb-20140013

Schneider, F., \& Hametner, B. (2014). The shadow economy in Colombia: Size and effects on economic growth. Peace Economics, Peace Science and Public Policy, 20(2), 293-325. https://doi.org/10.1515/peps-2013-0059

Strapuc, C., \& Hlaciuc, E. (2019). Public Governance and The Underground Economy. The USV Annals of Economics and Public Administration, 19(1 (29)), 142-152. www.annals.seap.usv.ro

Tanzi, V., \& Fund, I. M. (2014). The Shadow Economy, Its Causes and Its Consequences. International Seminar on the Shadow Economy Index in Brazil," Brazilian Institute of Ethics in Competition, July. https://citeseerx.ist.psu.edu/viewdoc/download?doi=10.1.1.581.4386\&rep=rep1\&t ype $=$ pdf

Williams, C. C. (2015). Cross-national variations in the scale of informal employment: An exploratory analysis of 41 less developed economies. International Journal of Manpower, 36(2), 118-135. https://doi.org/10.1108/IJM-01-2014-0021

Williams, C. C., \& Horodnic, I. A. (2017). Evaluating the relationship between social exclusion and participation in the informal sector in the European Union. International Journal of Manpower, 38(3), 489-503. https://doi.org/10.1108/IJM10-2015-0179

Wiseman, T. (2015). Entrepreneurship, corruption, and the size of US underground economies. Journal of Entrepreneurship and Public Policy, 4(3), 313-330. https://doi.org/10.1108/JEPP-04-2014-0018 